Available online at https://www.irjst.com/
International Research Journal of Science and Technology
ISSN:2707-3955
DOI: https://doi.org/10.46378/irjst.2019.010101

\title{
Determination of Selected Trace Metal in Banana Growing at Kola Shele, Arba Minch, Ethiopia
}

\author{
Tsegaye Fekadu Egza* \\ Department of Chemistry, Arbaminch University, Ethiopia
}

\begin{tabular}{|c|c|}
\hline & Abstract \\
\hline Published: 2019 & $\begin{array}{l}\text { A study was carried out to determine the accumulation of trace metal in the } \\
\text { banana sample by atomic absorption spectroscopy method. The metal } \\
\text { investigated where } \mathrm{Fe}, \mathrm{Zn}, \mathrm{Cu} \text {, Co and } \mathrm{Cd} \text {. The level of } \mathrm{Zn} \text { is highest whereas the } \\
\text { level of } \mathrm{Co} \text { and } \mathrm{Cd} \text { was lowest. The concentration of } \mathrm{Fe}, \mathrm{Zn}, \mathrm{Cu}, \mathrm{Co} \text { and } \mathrm{Cd} \text { were }\end{array}$ \\
\hline $\begin{array}{l}\text { Key Words } \\
\text { Trace metal } \\
\text { AAS } \\
\text { Banana }\end{array}$ & $\begin{array}{l}\text { found to be } 2.82,4.0,0.233,0,0 \text { and } 5.06,13.18,0.117,0,0 \text { in peal and flash of } \\
\text { banana respectively. The overall content of this trace metal in the banana } \\
\text { investigated where found to be within the permissible limit recommended by the } \\
\text { FAO/WHO. The result shows that the accumulation of trace metal in the banana } \\
\text { is of nutritional interest. }\end{array}$ \\
\hline
\end{tabular}

Copyright@2019:Tsegaye Fekadu Egza.This is an open access distribution, and reproduction in any medium, provided Access article distributed under the Creative Commons Attribution License the original work is properly cited License, which permits unrestricted use.

Citation:Tsegaye Fekadu Egza. "Determination of Selected Trace Metal in Banana Growing at Kola Shele, Arba Minch, Ethiopia", International Research Journal of Science and Technology, 1(1), 1-5 ,2019

\section{Introduction}

Bananas come prepackaged in their own yellow jackets and are available for harvest throughout the year. Bananas are a very good source of vitamins $\mathrm{B}_{6}$, potassium, dietary fiber, and manganese [1]. Some fruits like bananas offer great medical benefits. This is partly because bananas aid in the body's retention of calcium, nitrogen, and phosphorus, all of which work to build healthy and regenerated tissues and it can be used to fight intestinal disorders like ulcers. Bananas are one of the few fruits that ulcer patients can safely consume it neutralize the acidity of gastric juices, thereby reducing ulcer irritation by coating the lining of the stomach. Bananas are an excellent source of potassium. Potassium can be found in a variety of fruits, vegetables, and even meats, however, a single banana provides you with $23 \%$ of the potassium that you need on a daily basis. Potassium benefits the muscles as it helps maintain their proper working and prevents muscle spasms.

\footnotetext{
${ }^{*}$ Corresponding author :Tsegaye Fekadu Egza
}

Department of Chemistry, Arbaminch University, Ethiopia

Email: tsefik05@gmail.com
Bananas are also an excellent food for people who want to lose weight. Although they are rather high in calories (200 per banana) and cobs (51 gm), they are a great source of energy. A banana eaten before a workout can provide you with the necessary energy to complete a longer workout [2].

Trace metals', although not easily defined, is widely recognized and used. It is a member of a group of elements that exhibit metallic properties, which include the transition metals, some metalloids, lanthanides, and actinides. Heavy metals or trace metals are those with atomic weights from 63.546 to 200.590 and have density greater than five. They are highly toxic and can cause damaging effects even at very low concentrations [3]. They tend to accumulate in the food chain and in the body and can be stored in soft (e.g., kidney) and hard tissues (e.g., bone). Being metals, they often exist in a positively-charged form and can bind on to negatively-charged organic molecules to form complexes [1].

It is often difficult to determine how toxic a trace metal is. Toxicity depends not only on the level of the trace metal in the environment, but also where it is 
found in the environment (water, soil or air), the source (mining or natural rock breakdown), how acidic the environment is in the area of interest (trace metals are more of a problem in acidic areas), and whether the metal exists by itself or as part of larger chemical compounds [4].

Until 1920 it was believed that the total nutrient requirement of plants were fully satisfied by ten essential element : the seven inorganic elements $(\mathrm{N}, \mathrm{S}$, $\mathrm{P}, \mathrm{k}, \mathrm{Ca}, \mathrm{Na}$, and $\mathrm{Fe}$ ) supplied by the cultural solution as salts plus carbon (C) from carbon dioxide and hydrogen $(\mathrm{H})$ and oxygen $(\mathrm{O})$ from water. Recent knowledge has revealed that plants require at least seven other elements in trace amounts $(\mathrm{B}, \mathrm{Cu}, \mathrm{Cl}, \mathrm{Mn}$, Mo, Na, and Zn). [5].

\subsection{Iron}

Iron is an essential element in the production of red blood cells. Low intake of iron cause anemia, tiredness and pallid physique, while high intake may result in to hepatic megaly, cardiac infraction and nephric malfunction. The acceptable limit for human consumption of iron is 8 to $11 \mathrm{mg} / \mathrm{day}$ for infants as well as adults [6].

\subsection{Zinc}

zinc is an essential trace element, performs important biochemical functions and is necessary for maintaining health throughout life. Zinc constitutes about $33 \mathrm{ppm}$ of adult body weight and is essential as constituent of many enzymes involved in a number of physiological functions, such as protein synthesis and energy metabolism. The recommended dietary allowance of zinc is $15 \mathrm{mg}$ per day for men and $12 \mathrm{mg}$ per day for women. The acceptable limit for human consumption of zinc is $5 \mathrm{mg} / \mathrm{L}[6]$.

\subsection{Cadmium}

Cadmium is toxic metal with sterilizing, teratogenic and carcinogenic effects. It may also lead to cardiovascular diseases. Its toxicity affects many target tissues such as pain centers (in brain), brain, heart, blood vessels, kidneys and lungs. United State Department of Agriculture (USDA) limits $0.01 \mathrm{ppm}$ $\mathrm{Cd}$ in fruit and vegetable juice. FAO/WHO recommended a maximum limit of $70 \mu \mathrm{g} /$ day [6]. Cadmium displaces zinc in many vital enzymatic reactions, resulting in disruption or cessation of activity. This normally leads to acute gastroenteritis Recent epidemiologic studies involving exposure with some effect assessment have linked low level $\mathrm{Cd}$ exposure of current populations with some adverse effects that are not restricted to kidney and bone but include almost every organ and where $\mathrm{Cd}$ accumulates including eye tissue [7].

\subsection{Copper}

Copper is critical for energy production in the cells. It is also involved in nerveconduction, connective tissue, the cardiovascular system and the immune system.Copper is closely related to estrogen metabolism, and is required for women'sfertility and to maintain pregnancy. Normal values of $\mathrm{Cu}$ in Serum is $12-26 \mu \mathrm{mol} / \mathrm{L}$ and Urine is $0.05-0.55 \mu \mathrm{mol} / \mathrm{da}$ Deficiency of copper effect upon thyroid function caused Vascular lesions Central nervous system disorder and convulsion, Hair abnormalities. Hypercopper caused decreased hemoglobin and erythrocyte levels, death and cancer [5].

\subsection{Cobalt}

It is usually contributed with vitamin B-12 and its deficiency effect on the vitamin B-12 consistency in the body. it is rare in human and the daily recommended range of cobalt in diet is $0.005 \mathrm{mg}$ per day. Its deficiency also has an additional role in producing anoxia and injuring the heart muscle [7].

The toxicity of trace metals is attributed basically to the role they metals play in biological processes as well as the way they interact with essential elements both at intestinal and organ level once absorbed in the body. They are able to remove electrons from the amino-acids or bases of DNA that cause a reaction which disrupts the ability of the cell to carry out their biological functions. These modified biological molecules lose their ability to function properly and result in malfunction or death of the affected cells [8].

The poisoning effects of trace metals are due to their interference with the normal body biochemistry in the normal metabolic processes. When ingested, in the acid medium of the stomach, they are converted to their stable oxidation states and combine with the body's bio molecules such as proteins and enzymes to form very stable biotoxic compounds, which become difficult to be dissociated, due to their bio-stabilities, during extraction from the body by medical detoxification therapy. The equations below show their reactions during bond formation with the sulphydryl groups (-SH) of cysteine and sulphur atoms of methionine $\left(-\mathrm{SCH}_{3}\right)$ [8]. 


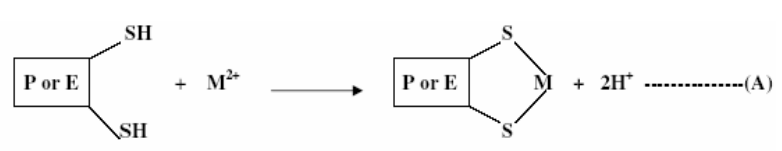

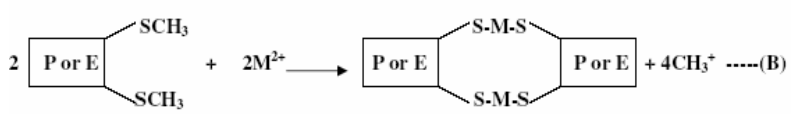

Figure 1. Trace metal reactions during bond formation

Figure 1.shows the metal reactions during bond formation with the sulphydryl groups (-SH) of cysteine and sulphur atoms of methionine $\left(-\mathrm{SCH}_{3}\right)$.

Where, A-intramolecular bonding; B-intermolecular bonding; P-protein; E-enzyme and M-metal.

The hydrogen atoms or the metal groups in the above case are replaced by the poisoning metal and the enzyme is thus inhibited from functioning, whereas the protein-metal compound acts as a substrate and reacts with a metabolic enzyme[8].

Trace metal have been reported to have positive and negative roles in human life because the body need in low level of construction if this level excess the effect came negative. Some like cadmium, lead and mercury are major contaminants of food supply and may be considered the most important problem to our environment while others like iron, zinc and copper are essential for biochemical reactions in the body. Generally, most trace metals have long biological halflives and have the potential for accumulation in the different organ of body leading to unwanted effect side. There is a strong link between micronutrient nutrition of plants, animals and humans and the uptake and impact of contaminants in these organisms [5].

Some trace elements (e.g., As, B, Co, Cr, Cu, Mo, Mn, $\mathrm{Ni}, \mathrm{Se}, \mathrm{Zn}$ ) are important as micro nutrients to living cells, although many trace elements ( $\mathrm{Zn}, \mathrm{As}, \mathrm{Hg}, \mathrm{Cd}$, $\mathrm{Pb}, \mathrm{Tl}, \mathrm{Co}, \mathrm{Cr}, \mathrm{Cu}, \mathrm{Mo}, \mathrm{Ni}, \mathrm{Se}, \mathrm{Sn}$ ) that are useful to living cells can be toxic above certain levels. Also, some elements ( $\mathrm{Ba}, \mathrm{Bi}, \mathrm{Cd}, \mathrm{Hg}, \mathrm{Pb}, \mathrm{Sb}, \mathrm{Tl})$ have unknown biological functions. However, toxicity is a problem of 'dose' and many elements are toxic until a specific concentration [9].The past few decades have generated consciousness of more diverse environmental pollution issues. One of the issues is the presence of trace metals in the banana from pesticides, insecticides and herbicides deposited onto soils and vegetation. The trace metals that contaminate the soils are taken up and transported to other parts of plants like banana. Humans are exposes to these trace metals through the food chain because food is essential for humans. Humans must take food as their daily diet for the nutrition which included banana. Banana is a good source of vitamin, minerals and antioxidants. Fruits also consist of the largest part of water that is around $75-95 \%$. The high concentration of trace metals in food can effect human health such as, lead $(\mathrm{Pb})$ causes chronic damage to the nervous system in humans; mercury causes damage to the brain and the central nervous system while the copper $(\mathrm{Cu})$ causes anemia, liver and kidney damage. Therefore this study aimed at assessing the levels and concentration of selected trace metals in banana in order to establish whether the users are exposed to high levels besides creating awareness.

Several techniques for determination of metallic elements are currently in use. These include the atomic absorption spectroscopy (AAS), inductively coupled plasma mass spectroscopy (ICP-MS), the inductively coupled plasma atomic emission spectroscopy (ICPAES) and energy dispersive X-ray fluorescence (EDXRF) spectroscopy. For this study, the AAS was used because of its availability, reproducibility and time efficiency. The AAS has high sensitivity and selectivity. It is a single elemental method in which one element is determined in a series of samples and instrumental parameters optimized for the next element and can easily be automated.

\section{Material and Methods}

\subsection{Sampling Sites}

Banana samples were collected from Arba Minch Southern Nation Nationalities and People State region, southern Ethiopia $505 \mathrm{Km}$ from the capital city Addis Ababa. The major farm lands is Kola Shele farming area were selected based on the irrigation techniques of farming land, were assumed to be the major source of some trace metal in the banana with a natural abundance of elements even in trace amounts.

\subsection{Sample Collection}

Banana sample were collected from cultivated area by using sample techniques. Banana sample were kept in polythene bags. Then these samples were brought to the laboratory and keep in air dried place prior to analysis of some trace metals.

\subsection{Sample Preparation}

The fruit samples collected were washed and rinsed thoroughly with tap water and the peel was removed. The fruits were then sliced into small pieces. The flesh and peels were ground separately. The peels and fleshes were ground into fine powder and the fruits into smooth paste. These samples require digestion 
before analysis so as to reduce organic matter interference by destroying all or most of the organic matter present in the sample. The ground samples were stored in sample containers ready for digestion. Most present in the sample into such a form that they can be analyzed with minimal interference.

\subsubsection{Banana Sample Digestion}

One gram of dried sample was placed in $250 \mathrm{ml}$ digestion tube and $10 \mathrm{ml}$ of concentrated nitric acid added. The mixture was boiled gently for 30-45 minute. After cooling, $5 \mathrm{ml}$ of $70 \%$ perchloric acid was added and the mixture boiled gently until dense white fumes appeared. Then $20 \mathrm{ml}$ of distilled water was added and the mixture was boiled further to release any fumes. The solution was cooled further and filtered through what man No. 42 filter paper into a 50 $\mathrm{ml}$ volumetric flask. The filtrate was made to the mark using distilled water.

\subsection{Standard Preparation}

Standard cadmium $(\mathrm{Cd})$, copper $(\mathrm{Cu})$, iron $(\mathrm{Fe})$ cobalt $(\mathrm{Co})$ and $\mathrm{Zinc}(\mathrm{Zn})$ solution were prepared from their

Table 1.Concentration of trace metals in banana sample $(\mathrm{mg} / \mathrm{L})$

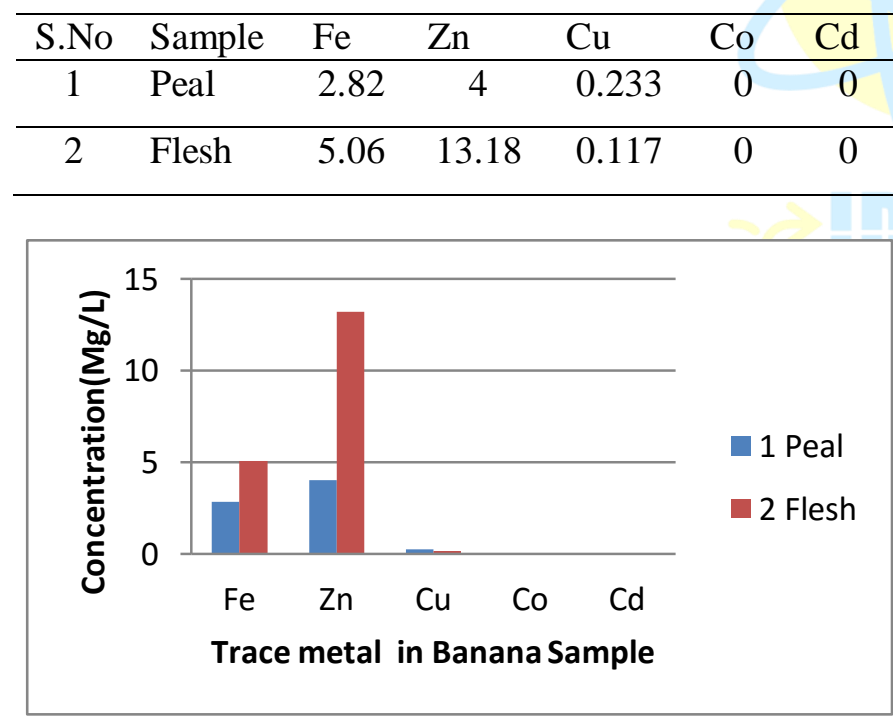

Figure.2 Comparison of some trace metal in banana

Table 2. Absorbance reading of trace metal in study sample

\begin{tabular}{ccc}
\hline Trace metal & Banana peal & Banana flesh \\
\hline $\mathrm{Zn}$ & 0.147 & 0.248 \\
\hline $\mathrm{Fe}$ & 0.090 & 0.128 \\
\hline $\mathrm{Cu}$ & 0.023 & 0.014 \\
\hline $\mathrm{Cd}$ & 0 & 0 \\
\hline $\mathrm{Co}$ & 0 & 0
\end{tabular}

stoke form by dilution process. $0.5 \mathrm{ml}, 1 \mathrm{ml}, 1.5 \mathrm{ml}, 2 \mathrm{ml}$, and $2.5 \mathrm{ml}$ of the standard $\mathrm{Cd}, \mathrm{Cu}, \mathrm{Fe}, \mathrm{Co}$ and $\mathrm{Zn}$ were pipette out into a series of $100 \mathrm{ml}$ volumetric flask. The flasks were filled by distilled water up to the mark. The flasks which contain banana sample were filled up by addition of distilled water up to the mark. Finally the concentrations of the resulting standard solution are $1 \mathrm{ppm}, 2 \mathrm{ppm}, 3 \mathrm{ppm}, 4 \mathrm{ppm}$ and $5 \mathrm{ppm}$ respectively. The solutions were taken for AAS analysis for determine concentration of some trace metals inbananasample[10].

\section{Results and Discussion}

Table1 shows the Trace metal concentrations in bananas peal and flash grown in Kola Shele farming area.The concentrations obtained for the metals are $2.82,4,0.23,0$ and $0 \mathrm{mg} / \mathrm{L}$ in peal of banana and 5.06, $13.18,0.12,0$ and $0 \mathrm{mg} / \mathrm{L}$ in banana flesh for $\mathrm{Fe}, \mathrm{Zn}$ $\mathrm{Cu}, \mathrm{Co}$ and $\mathrm{Cd}$ respectively.

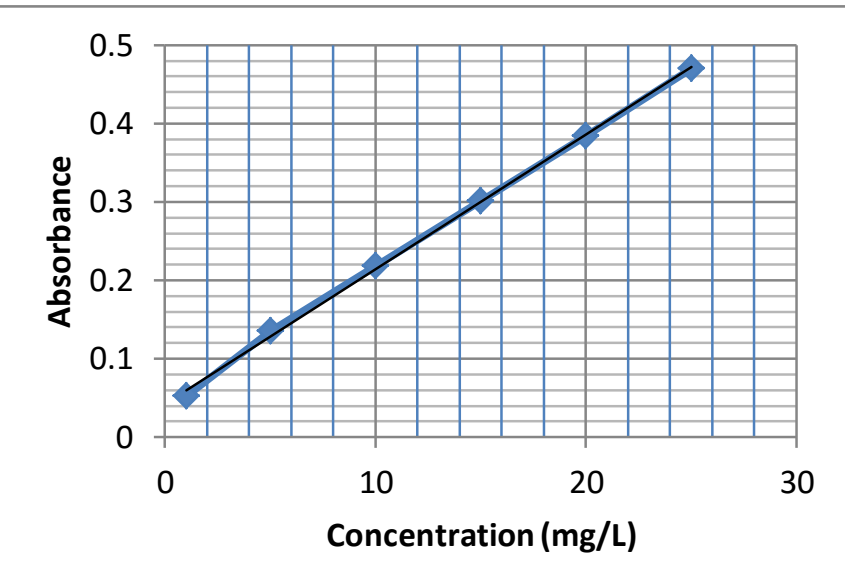

Figure3. Calibration curve for Fe

Based on the AAS data of standard concentration of metals, calibration curve for each trace metal was prepared as follow.

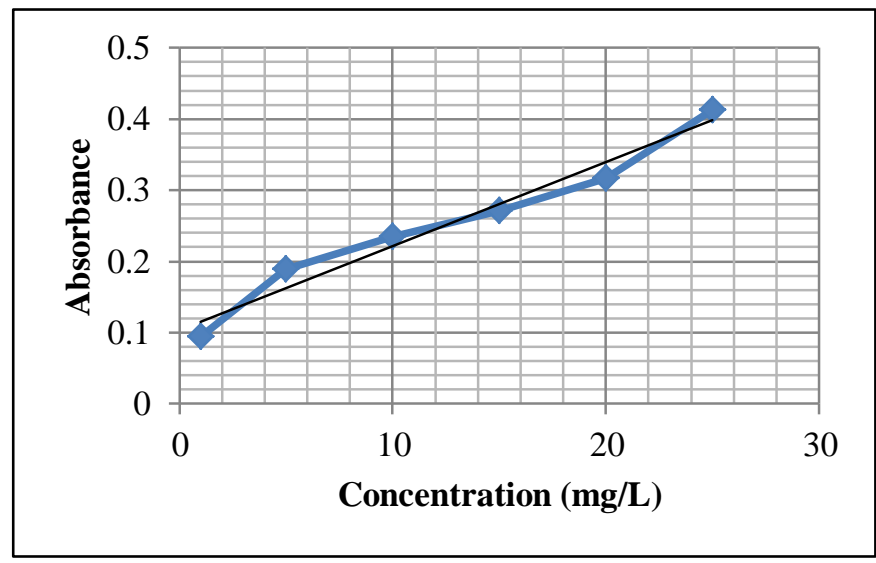

Figure.4 Calibration curve for $\mathrm{Zn}$ 


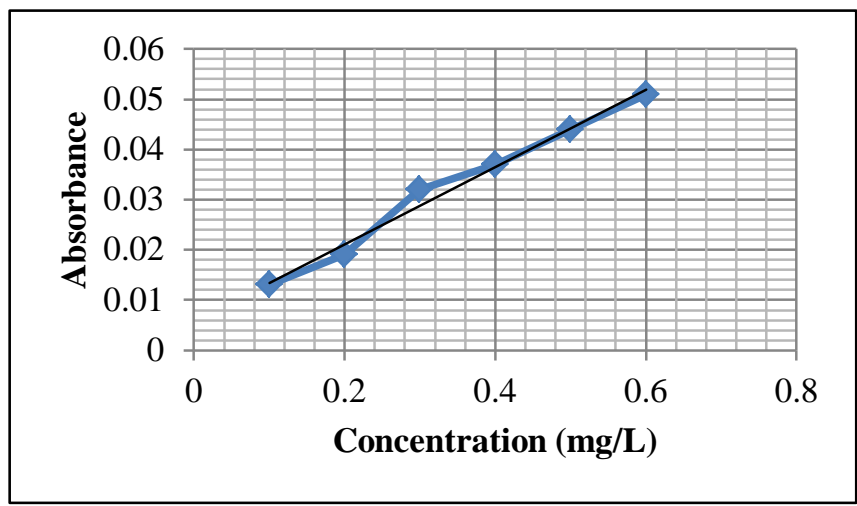

Figure.5 Calibration curve for $\mathrm{Cu}$

Table 3. FAO/WHO guideline for metal in food and vegetables

\begin{tabular}{cc}
\hline Metal $(\mathrm{mg} / \mathrm{kg})$ & WHO/FAO Standard \\
\hline $\mathrm{Cd}$ & 1 \\
\hline $\mathrm{Cu}$ & 30 \\
\hline $\mathrm{Zn}$ & 60 \\
\hline $\mathrm{Fe}$ & 48 \\
\hline $\mathrm{Co}$ & - \\
\hline
\end{tabular}

\section{Conclusions}

In this study, the concentration of trace metals ( $\mathrm{Fe}, \mathrm{Co}$, $\mathrm{Cd}, \mathrm{Cu}$, and $\mathrm{Zn}$ ) from Kola Shele banana samples were determined using Atomic Absorption spectroscopy (AAS) method. The concentration of trace metals determined were in sequence $\mathrm{Zn}>\mathrm{Fe}>\mathrm{Cu}>\mathrm{Co}=\mathrm{Cd}$ for banana sample with Zinc ( $\mathrm{Zn}$ ) having the highest concentration in the plant sample, while cobalt and cadmium had not present in the sample. Although these metals were found in banana sample is worthy of note that they were below WHO permissive levels. In general we conclude from this study the concentration of trace metals in the banana has no health effect onto consumer.

\section{Acknowledgement}

I would like toexpressmy sincere thanks and gratitude to the Department of Chemistry, Arba Minch University, Ethiopia for providing the laboratory facilities and the necessary supports.

\section{References}

[1] Anjali V., Priyanka S., Namita D., NandkishorM (2016) "Determination of heavy metal content in fruits and fruits juices consume in urban areas of Lucknow, India" International Journal of Food Science and Nutrition 1( 5) pp.44-50.
[2] Sampath Kumar K.P., Debjit B., Duraivel S., Umadevi M. (2012)"Traditional and Medicinal Uses of Banana" Journal of Pharmacognosy and Phytochemistry, 1(3)pp 51-63.

[3] International union of pure and applied chemistry and human health division clinical chemistry section, (2002) Commission on toxicology pure\& applied Chemistry, 74(5) pp. 793-807.

[4] Abdurrahman,M(2017) "Determination of trace metal in banana and soil in shale Arba Minch Ethiopia" Journal of Environmental Science, Computer Science and Engineering \& Technology, 6 (1) pp.24-33.

[5] Maha B. Omer (2012) “Assessment of Some Heavy Metals in Fruit from Local Market in Khartoum State".

[6] Gizaw T. (2015) "Determination of selected heavy metals in bottled mango drinks produced in Ethiopia." Ethiopian Journal of Science and Technology, 8(1) pp 1- 13.

[7] Ismail F, Aujum M. Mamon A. Kazi T. (2011) "Trace metal content of vegetables and fruit of Hyderpad retail market" Pakistan Journal of Nutrition, 10(4), pp.365-372..

[8] Sailus M. Ireri (2014) "Determination of the levels of selected heavy Metals in soil and in khat (Catha edulisforsk) grown in Kenya.

[9] Abbaslou,H.,. Martin F., Abtahi,A., Moor F., (2014)"Trace element concentrations and background values in the arid soils of Hormozgan Province of southern Iran" Archives of Agronomy and Soil Science, 60(8), pp 1125-1143.

[10] Kailas R. (2013) "Assessment of Heavy Metal Contamination in Vegetables Grown in and Around Nashik City, Maharashtra State, India" IOSR Journal of Applied Chemistry, 5(3) pp.9-14 . 